\title{
Elderly Saudi male patient with Osteomalacia presented to ER (first presentation) with recurrent focal Seizures due to severe hypomagnesemia
}

\author{
Abdalla Khalil ${ }^{1 *}$, Mohamed Elwakil $^{2}$, Walid Tantawi ${ }^{3}$, Hussien Ahmed ${ }^{4}$ and Shireen Alshareef \\ ${ }^{1}$ Department of Internal Medicine, International Medical Centre IMC Hospital, Saudi Arabia \\ ${ }^{2}$ Associate Consultant Emergency Medicine, IMC Hospital, Saudi Arabia \\ ${ }^{3}$ Department of Neurology, IMC Hospital, Saudi Arabia \\ ${ }^{4}$ Department of Emergency Medicine, IMC Hospital, Saudi Arabia \\ ${ }^{5}$ Department of Emergency Room, IMC Hospital, Saudi Arabia
}

Submission: May 28, 2017; Published: June 07, 2017

*Corresponding author: Abdalla Khalil, Department of Internal Medicine, International Medical Centre IMC Hospital, Consultant Internal

Medicine, Jeddah, Saudi Arabia, Email: abdallak59@gmail.com

Keywords: Osteomalacia ; Vitamin D deficiency; Focal seizures motor; Hypomagnesmia

Abbreviations: ER: Emergency room; EEG: Electro Encephalo Gram; PVC: Premature Ventricular Contraction; RBBB: Right Bundle Branch Block; OPD: Out Patient Department; ECG: Electro Cardio Gram; MRC: Medical Research Council scale of muscle strength

Abstract

Vitamin D deficiency and Osteomalacia are common among Middle East and Saudi Arabia population with a higher prevalence among females than in males. Hypocalcemic Seizures secondary to severe vitamin D deficiency have been reported as an extremely rare presentation in Pediatrics and adolescents. We are presenting an elderly Saudi male patient who came to our ER with a first presentation of recurrent multifocal motor seizures.

His neurological investigations were all normal together with absence of any urinary or gastrointestinal magnesium wasting. However, his biochemical studies were constant with osteomalacia besides significant low serum magnesium. Off note, we could not find any hypomagnesemic seizures in patient with osteomalacia in our literatures search. Checking serum electrolytes including magnesium is an essential work up for all ER patients with seizures.

\section{Introduction}

The Institute of Medicine has recommended that serum 25(OH)D is adequate when it is higher than $50 \mathrm{nmol} / \mathrm{l}$ [1]. However, Clinical vitamin D deficiency only occurs when serum $25(\mathrm{OH}) \mathrm{D}$ is lower than $25 \mathrm{nmol} / \mathrm{l}$.

In a review of vitamin $\mathrm{D}$ levels globally, vitamin $\mathrm{D}$ levels below $75 \mathrm{nmol} / \mathrm{L}$ were prevalent in different regions of the world, whereas vitamin D levels $<25 \mathrm{nmol} / \mathrm{L}$ were more common in South Asia and the Middle East than in other regions [2]. Off note, the lowest serum 25(OH)D was seen in an old study of older persons in Saudi Arabia with a mean of 9nmol/l [3].

In a study between 2011 and 2016, the prevalence of vitamin D deficiency $(<50 \mathrm{nmol} / \mathrm{l})$ in Saudi Arabia among different populations (adults, children and adolescents, newborns and pregnant/lactating women) was 81.0\% [4].

In the Saudi Health Interview Survey (SHIS), 62.65\% of female Saudis and $40.6 \%$ of male Saudis aged 15 years and above are deficient in vitamin D. Out of them, less than $1 \%$ males and less than $2 \%$ females consume vitamin D supplements [5].

The clinical picture includes muscle weakness, bone pain and fractures, while in children joint swelling and deformations prevail. In patients with rickets and osteomalacia serum $25(\mathrm{OH})$ D usually is lower than $15 \mathrm{nmol} / \mathrm{l}$ or even below the detection limit [6]. 
The clinical manifestations of osteomalacia may include bone pain and tenderness, muscle weakness, difficulty walking, and a waddling gait.

\section{Case Presentation}

A 63-year-old Saudi male patient was brought to ER of the IMC hospital by his companions with a history of twitching of left side of the face followed by convulsions of both left upper and lower limbs, loss of consciousness and stools incontinence. It was an acute episode occurred at home 30 minutes before reaching the hospital.

While he was in ER, another episode of twitching of left side of face and convulsions of left side of the body happened which lasted for 2 minutes. Ten minutes later, he became conscious, able to communicate and give history, yet he was complaining of headache and muscle pains.

He was complaining of left side numbness, dizziness (light headiness not spinning) and unsteadiness for two weeks preceding this attack of seizure. Consequently, he was seen by a neurologist in a private clinic and a CT brain was done which was reported normal. Because he is claustrophobic to MRI machine, MRI scan was not done.

There was no history of previous loss of consciousness, head injury or seizures. Furthermore, he did not have a history of fever, loose motions, palpitation, chest pain, sweating or shortness of breath and no gastrointestinal complaint.

Apart from mellitus type I and essential hypertension, the patient has no other medical illness or surgical procedure. His drug list includes, Lisinopril $5 \mathrm{mg}$ once daily orally, insulin glaigrine 12 units subcutaneously at bed time, regular insulin 4units subcutaneously before meal and aspirin $81 \mathrm{mg}$ once daily orally.

He has no history of herbal medicine, alcohol or illicit drug intake. He had no family history of Epilepsy and he was not aware of any inherited disease in his family members. His pulse was $80 / \mathrm{min}$ and regular, BP $110 / 70$, temperature was $36.6 \mathrm{C}$, Respiratory Rate 20/min, oxygen saturation was $98 \%$ at room air and capillary blood glucose was $9 \mathrm{mmol} / \mathrm{l} . \mathrm{v}$ On examination, he had a mild facial muscles weakness on the left lower quadrant and his power on left upper and lower limb was 4/5 according to MRC scale. The rest of his neurological exam was normal together with unremarkable respiratory and cardiac review.

Serum alkaline phosphatase was high $150 \mathrm{u} / \mathrm{l}(40-100 \mathrm{u} / \mathrm{l})$, yet the rest of liver functions including serum albumin were normal. Serum calcium was mildly low $1.90 \mathrm{mmol} / \mathrm{l}(2.10-2.55 \mathrm{mmol} / \mathrm{l})$, serum phosphorus was also low $0.43 \mathrm{mmol} / \mathrm{l}(0.87-1.45 \mathrm{mmol} / \mathrm{l})$, whereas serum magnesium was substantially low $0.09 \mathrm{mmol} / \mathrm{l}$ $(0.7 \mathrm{mmol} / \mathrm{l}-1.45 \mathrm{mmil} / \mathrm{l})$, thus a second sample was double checked by our chemistry lab to confirm.

Vitamin D total (250H vitamin $D 3+250 H$ vitamin D2) was significantly low $10 \mathrm{nmol} / \mathrm{l}(80-170 \mathrm{nmol} / \mathrm{l})$ and Para thyroid hormone was $8.0 \mathrm{pmol} / \mathrm{l}(1.50-6.80 \mathrm{pmol} / \mathrm{l})$. Complete blood count with differential and Coagulation profile were normal. His chloride was $96 \mathrm{mmol} / \mathrm{l}(98-111 \mathrm{mmol} / \mathrm{l}) \mathrm{CO} 2$ venous in renal function was $22 \mathrm{mmol}(22-28 \mathrm{mmol} / \mathrm{l})$. Blood urea nitrogen was normal and serum creatinine was 111 umol/l (55-110umol/l). Serum sodium, potassium, serum creatinine kinase and troponin were normal.

CT brain without contrast was normal and ECG showed normal sinus rhythm with occasional PVCs, incomplete RBBB and normal QT interval. Based on magnesium level, intravenous infusion was started in ER. The provisional diagnosis was focal seizures for investigation; as a consequence, he was reviewed and admitted by neurology team with endocrinology and internal medicine co-management. MRI brain was unremarkable and normal awake to drowsy EEG recording.

His urinary magnesium in 24 hours (sent out of hospital chemistry test) was $20 \mathrm{mg} / 24$ hours (50- $250 \mathrm{mg} / 24$ hours). Intravenous magnesium infusion continued with repeated serum levels of calcium, magnesium and phosphorus. He was also on oral cultrate tablets (calcium elemental $600 \mathrm{mg} \&$ vitamin D 400 units) orally tree time's daily and vitamin D cholecalciferol 50.000 units once weekly.

Fortunately, the patient had not any more seizures, dizziness, muscle twitching, or weakness and he was ambulating with a good balance. His serum magnesium level improved with intravenous magnesium and he was switched to oral magnesium oxide tablets $800 \mathrm{mg}$ bid. Four days later, he was discharged home on his oral medications. On internal medicine outpatient clinic follow up, his serum magnesium level was maintained and oral magnesium was stopped after 2 weeks. His vitamin D level was normalized after 5 months and his serum magnesium was normal without supplements.

\section{Case Discussion}

Hypomagnesmia is a common problem among patients admitted to hospital with a higher percentage among intensive care units' patients (up to 65\%) [7]. Seizures in severely hypomagnesemic patients may be generalized tonic clonic or multifocal motor [8]. Low vitamin D level has been reported among patients with hypomgnesemia [9]. Hypocalcemic Seizures has been reported with osteomalacia in pediatrics and adult medicine $[10,11]$.

In our electronic search, we could not find any seizures due to severe hypomagnesemia among patients with vitamin D deficiency in adults or Pediatrics. Our elderly male patient was seen in ER with first focal motor seizure. His work up showed biochemical markers for severe vitamin D deficiency osteomlacaia. His serum calcium was slightly low which cannot be incriminated for the seizures, but magnesium was significantly low which is explaining the occurrence of repeated focal motor Seizures. In addition, there was no history of diarrhea or having 
malabsortion symptoms to point out gastrointestinal loss. His 24 hours magnesium was normal, so magnesium urinary wasting was also rolled out.

This association between severe hypomagnesemia with osteomalacia and focal Seizures has not been reported before in literature. It is essential to check serum electrolytes including sodium, calcium and magnesium for all patients coming to ER with seizures to complete work up for seizures assessment [12].

\section{References}

1. Ross AC, Manson JE, Abrams SA (2011) The 2011 report on dietary reference intakes for calcium and vitamin $D$ from the Institute of Medicine: what clinicians need to know. The Journal of Clinical Endocrinology \& Metabolism 96(1): 53-58.

2. Mithal A, Wahl DA, Bonjour JP (2009)Global vitamin D status and determinants of hypovitaminosis D. OsteoporosInt 20(11): 1807-1820.

3. Sedrani SH, Elidrissy AW, El Arabi KM (1983) Sunlight and vitamin D status in normal Saudi subjects. The American Journal of Clinica Nutrition 38(1): 129-132.

4. NM Al Daghri (2016) Vitamin D in Saudi Arabia: Prevalence, Distribution and Disease Associations. J Steroid BiochemMol Biol. doi. org/10.1016/j.jsbmb.2016.12.017.

5. Tuffaha M, El Bcheraoui C, Daoud F, Al Hussaini HA, Alamri F, et al (2015) Deficiencies Under Plenty of Sun: Vitamin D Status among

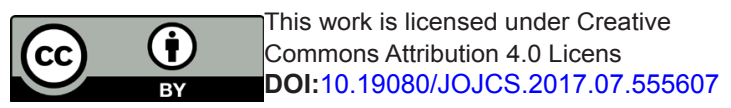

Adults in the Kingdom of Saudi Arabia, 2013. N Am J Med Sci 7(10): 467-475.

6. Need AG, O'Loughlin PD, Morris HA (2008) Vitamin D metabolites and calcium absorption in severe vitamin D deficiency. J Bone Miner Res 23(11): 1859-1863.

7. Tong GM, Rude RK (2005) Magnesium deficiency in critical illness. J Intensive Care Med 20(1): 3.

8. Mody I, Lambert JD, Heinemann U (1987) Low extracellular magnesium induces epileptiform activity and spreading depression in rat hippocampal slices. J Neurophysiol 57(3): 869-888.

9. Rude RK, Adams JS, Ryzen E, Endres DB, Niimi H, et al. (1985) Low serum concentrations of 1,25-dihydroxyvitamin D in human magnesium deficiency. J Clin Endocrinol Metab 61(5): 933-940.

10. Vuletić B, Marković S, Igrutinović Z, Vladimir R, Rasković Z, et al (2016) Case Report of infant with severe vitamin D deficiency Rickets manifested with hypocalcemic seizures. Srp Arh Celok Lek 144(1-2): 90-93.

11. Korkmaz HA, Dizadrer C, Ecevit CO (2013) Hypocalcemic seizure in an adolescent with Down syndrome: a manifestation of unrecognized celiac disease. Turk J Pediatr 55(5): 536-538.

12. Nardone R, Brigo F, Trinka E (2016) Acute Symptomatic Seizures Caused by Electrolyte Disturbances. J Clin Neurol 12(1): 21-33.

\section{Your next submission with Juniper Publishers} will reach you the below assets

- Quality Editorial service

- Swift Peer Review

- Reprints availability

- E-prints Service

- Manuscript Podcast for convenient understanding

- Global attainment for your research

- Manuscript accessibility in different formats

( Pdf, E-pub, Full Text, Audio)

- Unceasing customer service

Track the below URL for one-step submission https://juniperpublishers.com/online-submission.php 